\title{
Alternative light colors in suckling piglet creep area: preference and validation tests in swine maternity
}

\author{
Ana Caroline Paggi ${ }^{*}$ (D) Taciana Aparecida Diesel $^{2}$ iD \\ Paulo Armando Victoria de Oliveira ${ }^{3}$ (D) Arlei Coldebella ${ }^{3}$ iD Diovani Paiano $^{1}$ (D \\ Victoria Carolina Bonassi Marcanzoni ${ }^{2}$ Maria Luisa Appendino Nunes Zotti ${ }^{1}$ iD
}

\author{
${ }^{1}$ Programa de Pós-graduação em Zootecnia, Universidade do Estado de Santa Catarina (UDESC), Chapecó, SC, Brasil. E-mail:

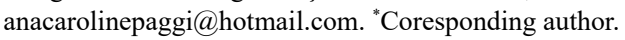 \\ ${ }^{2}$ Curso de Zootecnia, Universidade do Estado de Santa Catarina (UDESC), Chapecó, SC, Brasil \\ ${ }^{3}$ Embrapa Suínos e Aves, Concórdia, SC, Brasil.
}

\begin{abstract}
We performed a two-stage experiment: a preference and a validation test in swine litters, to determine whether suckling piglets preferred alternative light colors in their creep area over white light; we also determined whether the preferred color affected piglet behavior. In the first stage, five trials of two consecutive days were performed, each at 21-day intervals. In each trial, 40 piglets, from three to five days old, from four F1 sows (Large White x Landrace), were distributed in four treatments, in a paired scheme, receiving the following treatments: Treatment GR: white light vs. green light; Treatment BL: white light vs. blue light; Treatment YE: yellow light vs. white light; Treatment RD: white light vs. red light. For the validation test, three consecutive lots of eight F1 sows (Large White $x$ Landrace) and their corresponding maternity were used, remaining from birth under the influence of treatments $T$ Gr and $T$ Wh, totaling three replicates. $T$ _Gr corresponded to four creep areaswith green LED light and $T_{-}$Wh to four nurseries with white $\bar{L} E D$ light. The piglets showed a significant preference only for white over blue. Among the alternative colors, piglets significantly preferred green. In the validation stage, there was no significant effect of colors on the mean percentage of permanence of the piglets inside the creep areas over all evaluated periods. Piglets between two and five days of age prefer green lighting; however, in the creep area, the light color used did not influence piglet behavior.
\end{abstract} Key words: maternity, color, ambience, LED.

Cores alternativas de luz de abrigos escamoteadores para leitões lactentes: teste de preferência e validação em maternidade suína

RESUMO: Foi realizado um experimento de duas etapas: teste de preferência e validação em maternidade suína, para verificar se leitões possuem preferência por cores alternativas de luz do abrigo escamoteador em relação à luz branca, e o efeito da cor de luz preferida em teste realizado em abrigos escamoteadores (cor alternativa e branca) no comportamento de leitões. Na primeira, foram realizados cinco ensaios de dois dias cada, em intervalos de 21 dias. Quarenta leitões, entre três e cinco dias de vida, provenientes de quatro matrizes F1 (Large White $x$ Landrace), foram distribuidos em quatro tratamentos, em esquema pareado: Tratamento Vd: luz branca/luz verde; Tratamento Az: luz branca/luz azul; Tratamento Am: luz amarela/luz branca; Tratamento Vm: luz branca/luz vermelha. Para a validação, três lotes consecutivos de oito matrizes F1 (Large White x Landrace) e suas leitegadas permaneceram desde o nascimento sob os tratamentos $T \_V d$ e $T$ B Br. $T$ _Vd correspondia a quatro escamoteadores com luz de LED verde e T Br a quatro escamoteadores com luz de LED branca. A comparação entre cada cor alternativa e o branco mostrou diferença quanto à preferência $(p<0,05)$ apenas para o azul. Entre as cores alternativas os leitões preferem a cor verde $(p<0,05)$. Na etapa de validação, não houve efeito $(p>0,05)$ no percentual médio de permanência dos leitões no interior dos escamoteadores, entre as cores de luz, para todos os periodos avaliados. Leitões entre dois a cinco dias de vida preferem a iluminação verde, porém no ambiente de maternidade, a cor de luz utilizada não influenciou no comportamento dos leitões.

Palavras-chave: abrigo escamoteador, cor, ambiência, LED.

\section{INTRODUCTION}

Nursing is considered one of the most critical phases of commercial pig farming, not least because of the high mortality rates among newborn piglets (LARSEN et al., 2017) attributable to the inability of the developing thermoregulatory system to maintain homeothermia(FERREIRA et al., 2007).
Creep areas are used to prevent hypothermia, as they provide a warm environment without compromising piglet thermoregulation (XIN and ZHANG, 2006; LARSEN and PEDERSEN, 2015). During the first days after birth, time spent in a warm environment reduces the chances of being crushed by the mother(VASDAL et al., 2009).

Newborn piglets are able to perceive auditory, olfactory, tactile and visual stimuli.(ROHDE 
and GONYOU, 1991). Therefore, it appears necessary to make these nursing shelters more attractive for piglets, as this would encourage them to access the area more often(VASDAL et al., 2010a).

Piglets are influenced by light conditions, photoperiods, intensities and spectral characteristics (TAYLOR et al., 2006), and can demonstrate preferences for specific colors of objects such as drinkers and feeders (DELIGEORGIS et al., 2005; KLOCEK et al., 2016). However, KITTAWORNRATand ZIMMERMAN (2010) reported that, despite the fact that pigs have some ability to discriminate colors, there is little information regarding their visible spectrum and even less regarding the impact of color on piglet behavior.

There are no studies demonstrating piglet preferences specific light colors that might increase the attractiveness of the creep area. Therefore, the objectives of the current study were to determine whether piglets have a preference for particular light colors over white light in the creep area, to determine effect of the preferred light color on piglet behavior.

\section{MATERIALS AND METHODS}

The experiment was conducted on an experimental swine farm located in the western region of Santa Catarina, Brazil; the experiment consisted of two steps: a preference test and a validation test in pig maternity.

\section{Preference test}

Treatments - Preference test

In this stage, there were five trials of two consecutive days each, at 21-day intervals, to assess piglet preference for particular light colors vs. white light in the shelter. In each trial, 40 piglets, between three and five days old, from four F1 (Large White x Landrace) sows, were distributed in four treatments, in a paired scheme, as follows:

TreatmentGR: white light vs. green light;

Treatment BL: white light vs. blue light;

Treatment YE: white light vs. yellow light;

Treatment RD: white light vs. red light.

\section{Experimental device-Preference test}

The 24- $\mathrm{m}^{2}$ experimental room consisted of four paired test areas, each considered a treatment (Figure 1), arranged on suspended plastic floor with a central corridor.Each paired test area was $3.94 \mathrm{~m}^{2}$ $(1.63 \times 2.42 \mathrm{~m})$ with two black plywood chipping boxes measuring $0.55 \mathrm{~m}$ wide, $1.63 \mathrm{~m}$ long $\left(0.89 \mathrm{~m}^{2}\right)$

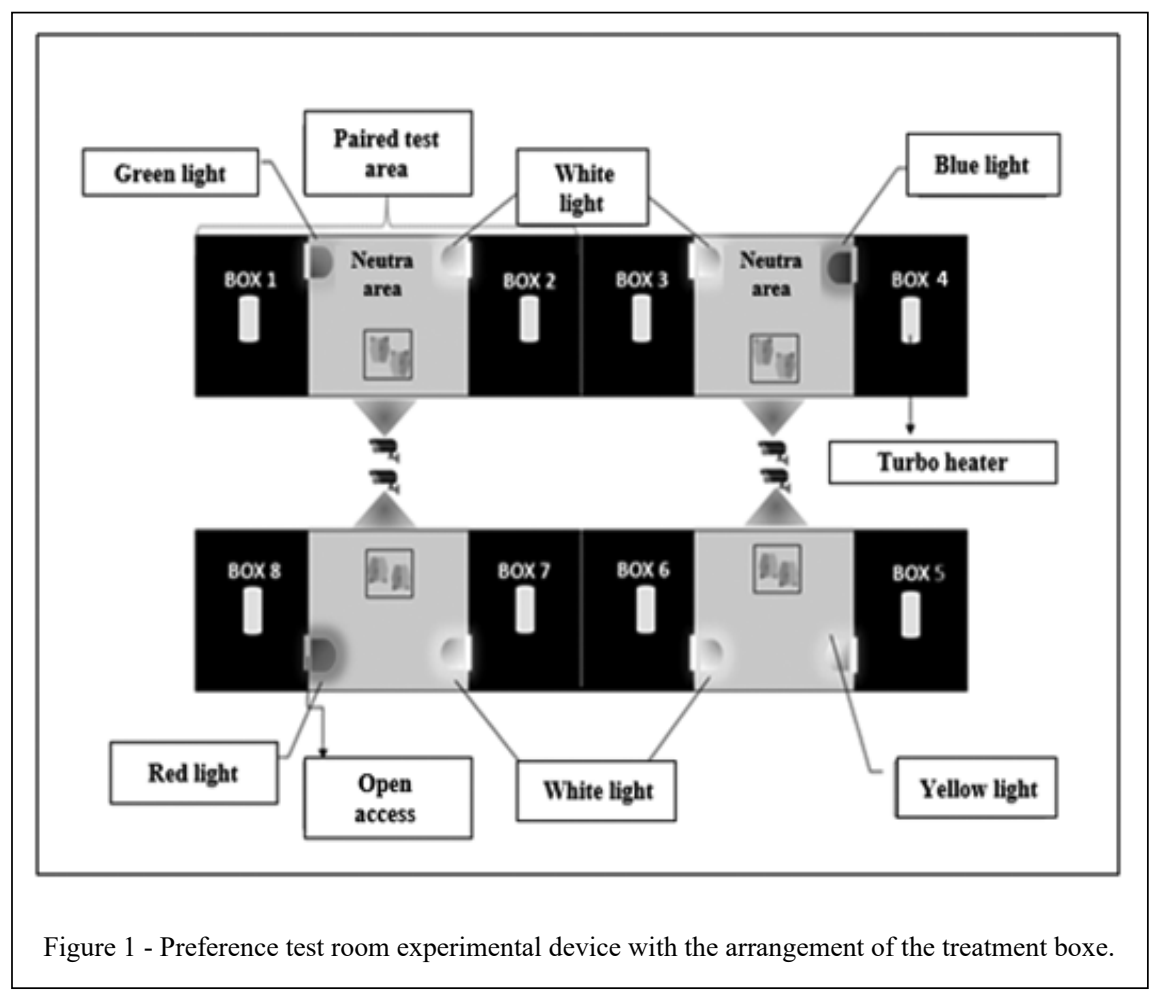

Ciência Rural, v.50, n.11, 2020. 
and $0.57 \mathrm{~m}$ high, facing each other at a distance of $1.32 \mathrm{~m}$ from one another. The area between the two creep areas corresponded to the neutral area of the test and the boxes were equipped with white and various color lamps, respectively. Each paired test area had a neutral area, and two open-access concealer boxes, each containing a lamp color to be used in the preference test.

Each creep area (box) had a $0.23-\mathrm{m}$ wide, $0.33-\mathrm{m}$ high piglet access door and was equipped with a 7-watt Ourolux ${ }^{\circledR}$ brand LED lamp of a specific color, depending on the box. Each contained a commercially-available convective heating system (electrical resistance and internal ventilation) called an electronic turbo heater (TELEISO ${ }^{\circledR}$ EST Temperature Controller). The color lighting system was adapted according to the treatment used.

Temperature and relative humidity (Figure 2) were measured from the external environment of the experimental room and from the interior of each of the maternity boxes, using TESTO $^{\circledR} 174 \mathrm{H}$ dataloggers. Directed toward each of the paired test areas was a HIKVISION ${ }^{\circledR}$ infrared video camera, four in total, mounted on the ceiling of the room (Figure 3), used for recording the test. The cameras were connected to a DVR video recording and storage system.

\section{Structure of the preference test and behavioral score \\ The preference of piglets for a particular light color vs. white was determined using a}

methodology developed from a sequence of observational studies of piglet behavior prior to the experiments. These studies were not reported in the present methodology, but rather served as a basis for experimental design, because of the scant amount of research using the same characteristics and purposes. We also used adaptations of the methodology described by VASDAL et al. (2010b).

Five trials were performed and, during each trial, 40 piglets were taken from the maternity ward and transported to the testing room. Groups of ten piglets were placed in the neutral area of the paired test areas (in total four groups of ten piglets, each group occupying a paired test area). Piglets were introduced into a bottomless, lidless plywood box that was $0.5 \mathrm{~m}$ wide, $0.5 \mathrm{~m}$ long and $0.5 \mathrm{~m}$ high where they were contained (about 30 seconds) until the test began, at which time the room lights were turned off, the box was removed and all piglets from all matched test areas were free to move, beginning the 1-hour test period.

After this period, the piglets were removed from the room and transported to the maternity to feed, about 10 to 15 minutes, after which they were collected and transported to the test room for a new test, in a new paired test area. In this manner, the litter occupied the four rotated paired test areas throughout the day (two tests in the morning and two tests in the afternoon), such that, at the end of the day, they all passed through all four paired test areas, completing the rotation (Figure 4). The following day, the same litter was used with the same rotation.

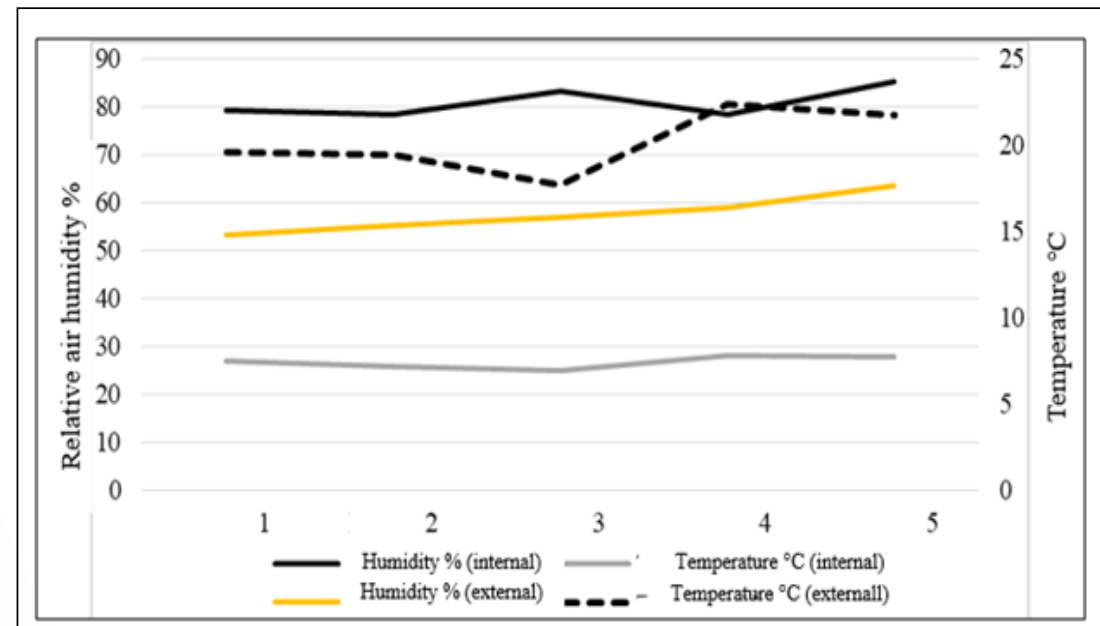

Figure 2 - Average temperature and relative air humidity of the external and internal environment (nursing rooms) used in the preference test. 


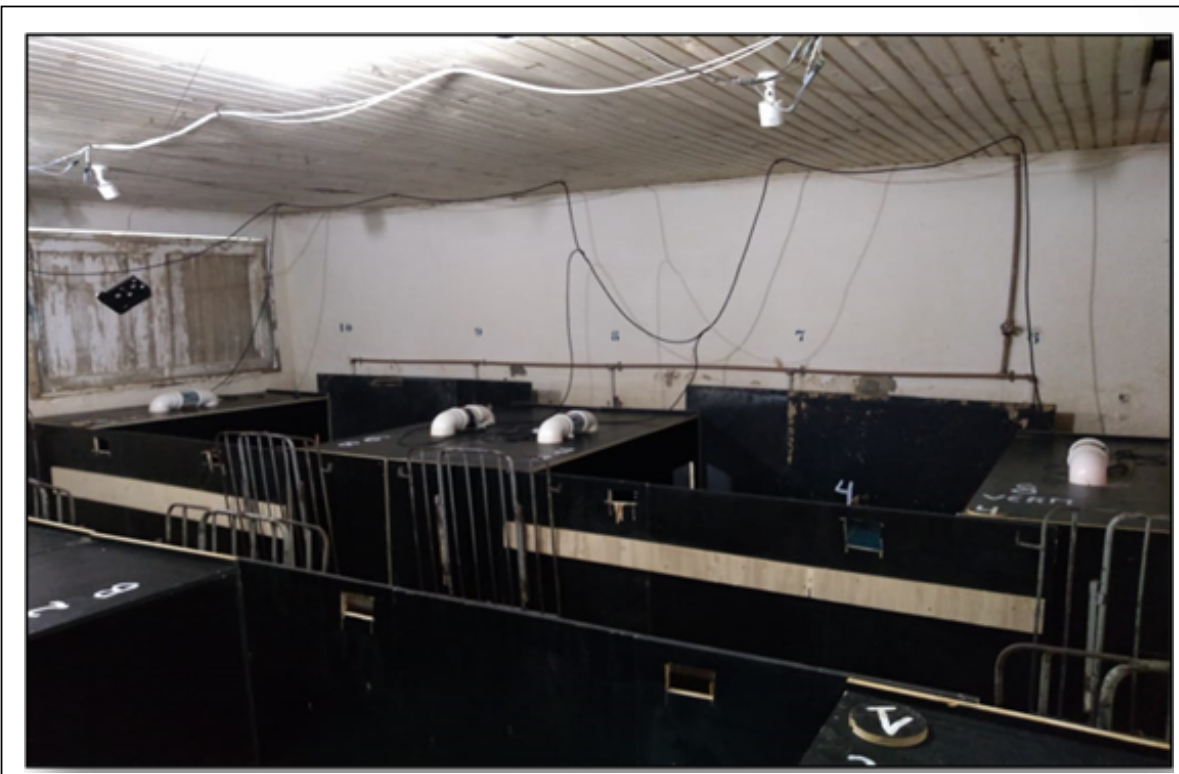

Figure 3 - Arrangement of treatments and video cameras in the preference test room.

A trained observer performed the behavior assessment using video analysis. Every 2 minutes, the number of piglets in each room of the paired test area (neutral area, white light and alternative color) was recorded over 60 minutes.In summary, throughout the experiment, there were five trials of two-days' duration (ten experimental days), with each trial involving four litters, totaling 20 litters (200 piglets).

\section{Statistical analysis - Preference test}

To perform the analyses, the average percentage of piglets remaining in each room was calculated for each evaluated litter and paired test area. Subsequently, a statistical analysis was performed comparing the white light with each particular color using the t-test. Finally, to compare the preferences among various light colors, the detail

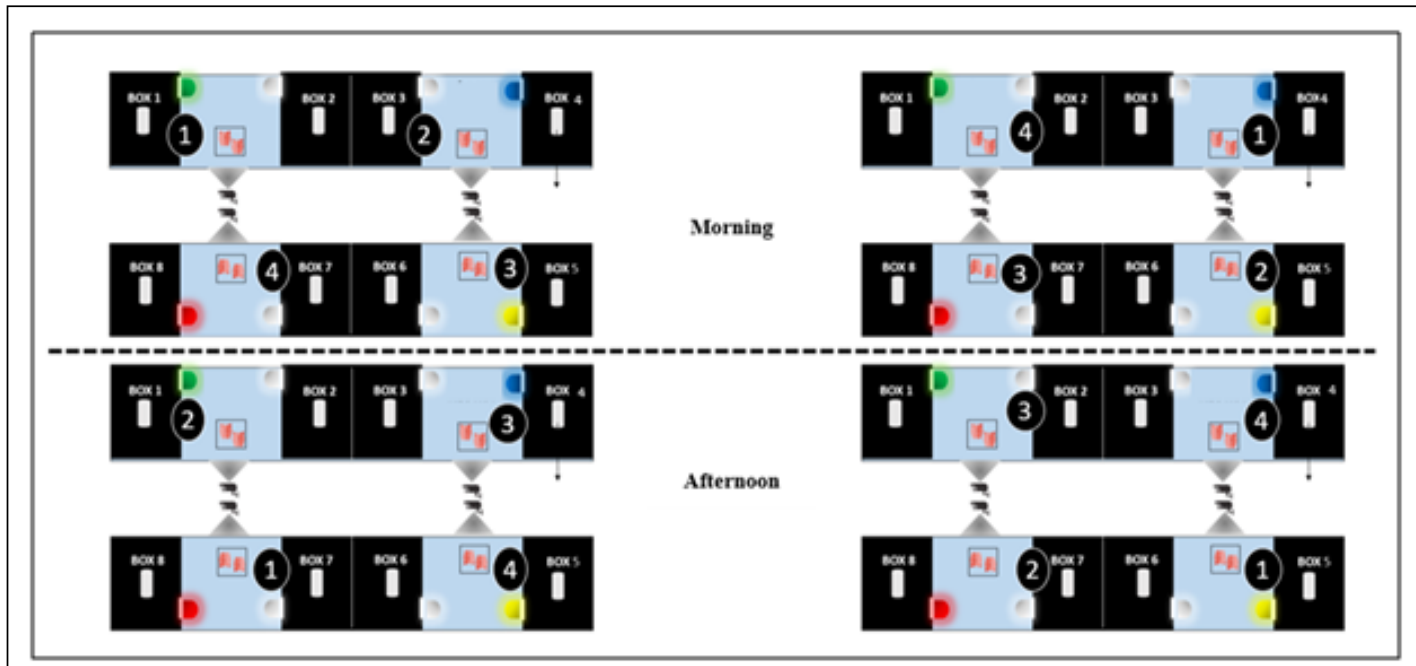

Figure 4 - Rotation performed during the preference test in the morning and afternoon.

Ciência Rural, v.50, n.11, 2020. 
of the light color effect were analyzed using the Wilcoxon test to compare treatments two-by-two whenever the Kruskal-Wallis test detected significant effect $(\mathrm{P} \leq 0.05)$. Analyses were performed using the program NPAR1WAY in SAS (2012).

\section{Validation of the swine maternity}

In the swine maternity of the experimental farm, the preference of suckling piglets was validated using green and white nursing shelters. The preference for the respective colors was obtained in the previous experiment, by testing the preference for green, blue, yellow and red, compared with white light, performed in a test room on the same experimental farm.

\section{Treatments - validation}

For validation, we used three consecutive lots of eight F1 sows (Large White $\mathrm{x}$ Landrace), and their corresponding litters that remained from birth under the influence of T_Gr and T_Wh treatments, totaling three replications. The T_Gr corresponded to four creep areas with green LED light and T_Wh corresponded to four creep areas with white LED light. The duration of both was different between lots, because of the routine management of the farm: 10 days for the first and second batchs, and 21 days for the third batch.

\section{Experimental device - validation}

The experimental device was structured in a nursing room (Figure 5) that had an area of 65 $\mathrm{m}^{2}$, built of masonry with a wooden ceiling. The room had four $1.15-\mathrm{m}$ high, $2.75-\mathrm{m}$ wide windows positioned on the sides, providing natural lighting and ventilation. The room had eight galvanized steel sidewalks, with plastic floors, distributed in two rows, four on each side and a corridor in the center. All farmyard stalls had 0.65-m wide black plywood, 1.0$\mathrm{m}$ long and $0.60-\mathrm{m}$ high, with a $0.23-\mathrm{m}$ wide, $0.33-$ high piglet access door. Nurseries were equipped with green (5-Watt TASCHIBRA ${ }^{\circledR}$ brand) or white (6-watt LUMINATTI brand) LED lamps, depending on the treatment. Each space contained a convective heating system (electrical resistance and internal ventilation), commercially-available electronic turbo heater (TELEISO ${ }^{\circledR}$ EST Temperature Controller). This system adapted according to the treatment used.

In every two bays was a HIKVISION ${ }^{\circledR}$ brand infrared video camera, four in total, mounted on the ceiling of the room, $5 \mathrm{~m}$ high, used for recording

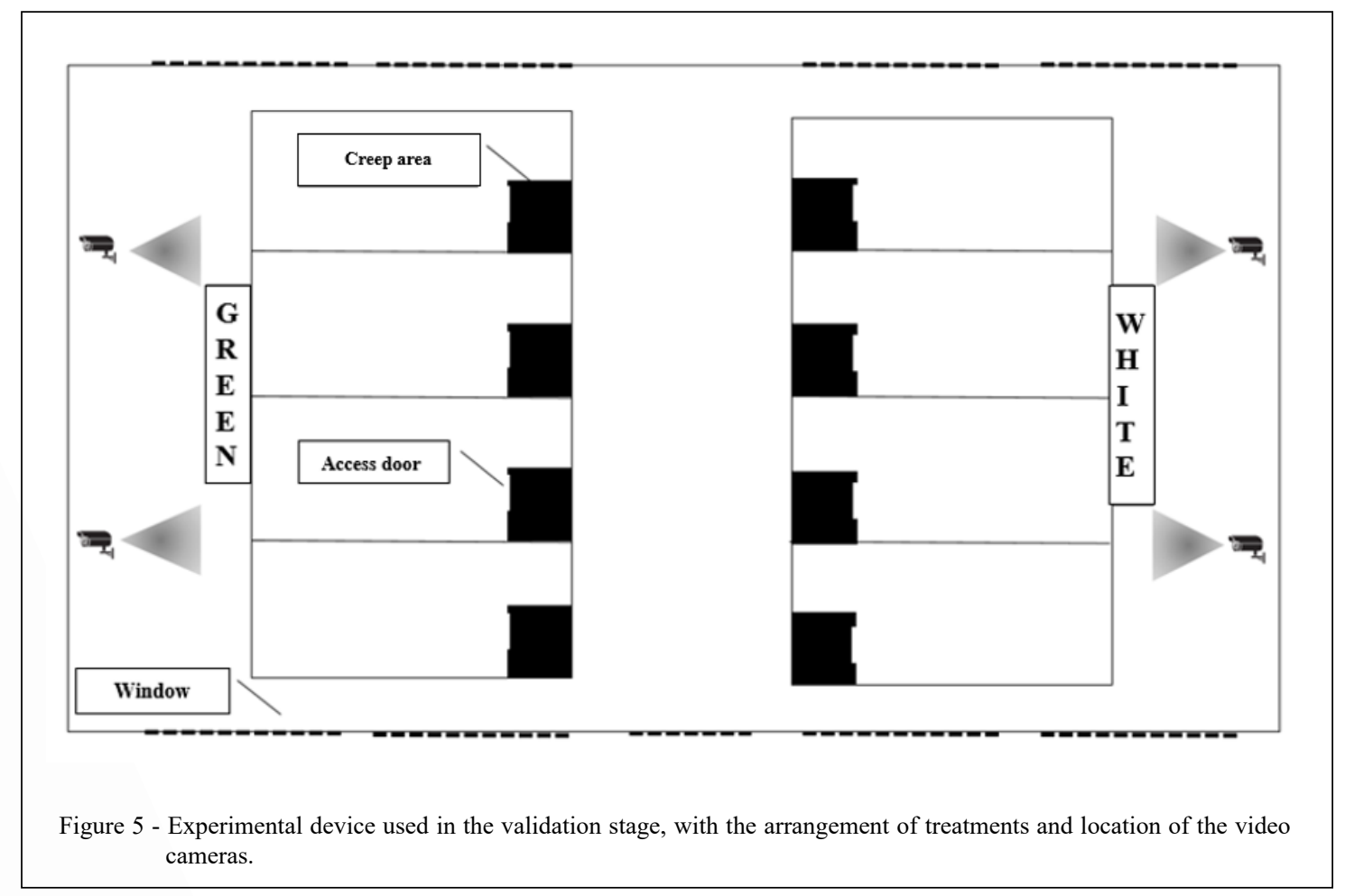

Ciência Rural, v.50, n.11, 2020. 
the experiment, connected to a DVR for data storage. Temperature and relative humidity records of the room's external environment were measured using two TESTO ${ }^{\circledR} 174 \mathrm{H}$ dataloggers throughout the experimental period.

\section{Behavioral assessment - validation}

Behavior was assessed using video analysis and hourly recording of the proportion of piglets outside the nursing shelter for 24 hours. The evaluation started from the fourth day after the birth of the piglets until the $10^{\text {th }}$ day (first and second lots) and until the $21^{\text {st }}$ day (third lot). Due to technical problems, some movie files were lost (around 4 days of recording). Nevertheless, this loss did not compromise the analysis of the second repetition of the experiment.

\section{Statistical analysis - validation}

The average percentage of permanence of the piglets in the maternity was calculated for each litter. Statistical analysis of the average percentage of permanence of the piglets in the maternity was performed by the nonparametric Wilcoxon test to evaluate the color of light. The analysis was performed using the SAS NPAR1WAY package(2012).

The same analysis was also performed considering the coldest period of the day (from $0200 \mathrm{~h}$ to $0900 \mathrm{~h}$ ), so as to filter the data in which the piglets remained in greater proportion inside the nursing shelter. Considering that the age of the piglets could also affect the stay inside the shelter (lower permanence of the older piglets), the data were also analyzed considering the total period and only the first ten days of age, assuming, in this period, there is a longer permanence of piglets inside the maternity.

\section{RESULTS AND DISCUSSION}

In the comparison between each particular color, piglets showed significant preferences only for white light over blue and red light (Figure 6). The rejection of blue and red light by the piglets differed from results of most studies involving discrimination and color preference in pigs.

TANIDA et al (1991) found that weaned piglets were able to discriminate only blue feeders from green, gray and red. The preference for blue was report-

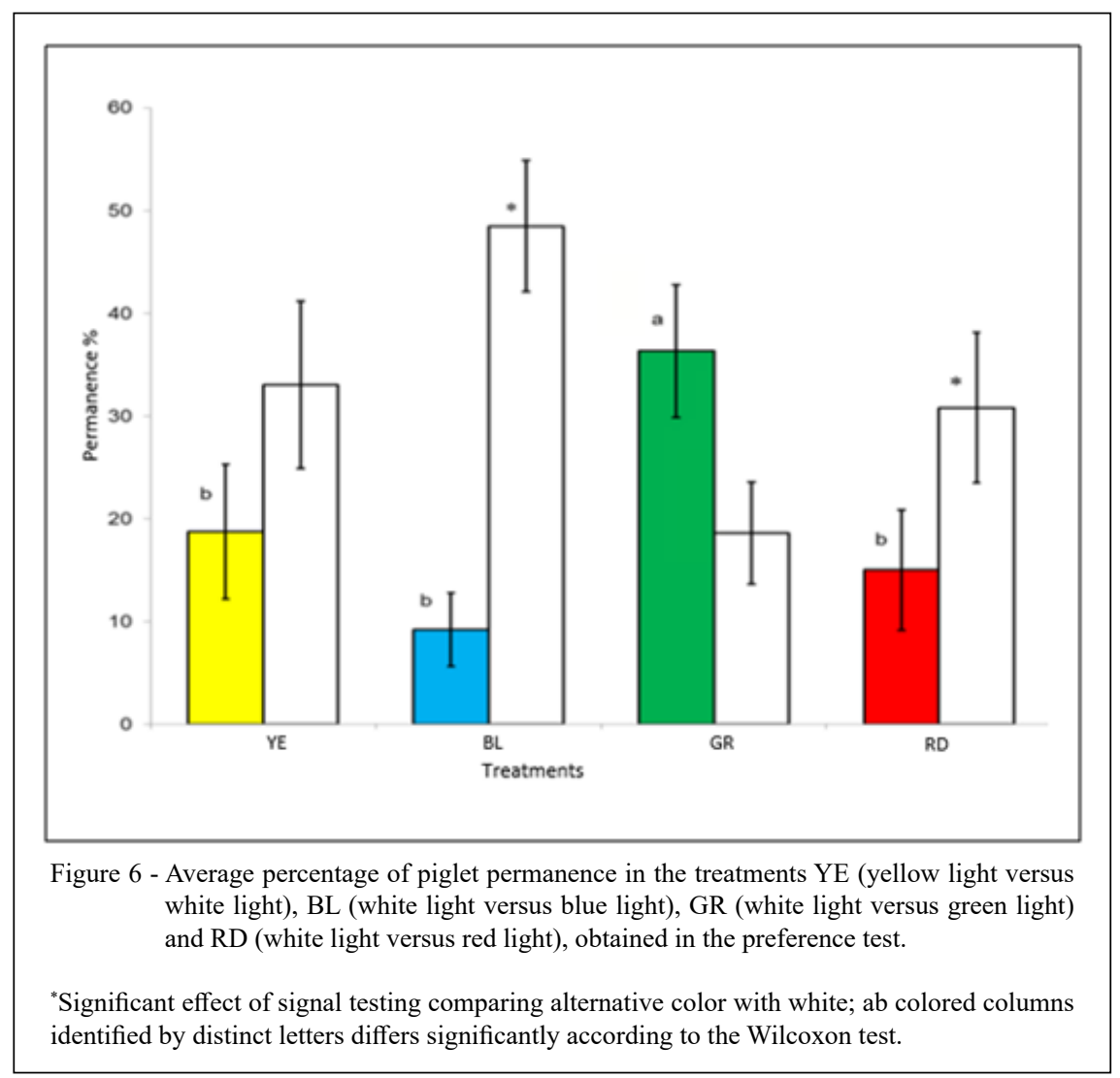

Ciência Rural, v.50, n.11, 2020. 
ed by KLOCEK et al. (2016), in which weaned piglets spent more time, visited more often and ate more food from blue feeders than from red or yellow feeders.DELIGEORGIS et al. (2005) reported that newborn piglets were more attracted to red and blue drinking troughs; however, there was a predilection that the authors claim to be related to sex, because females had a higher preference for blue drinking troughs, determined by the greater number of accessions compared to males. In addition, pigs are known to have a higher sensitivity to blue wavelengths (EGUCHIT, 1997; TAYLOR, 2010). Pigs have lower sensitivity for red(TAYLOR, 2010).

Previous studies reported the piglet preference for the color blue based on different-colored objects; our objective was to determine preference for the color of the lighting system. However, the color perception of an object, such as feeders and drinkers, may differ from the color perception of light, because the luminous intensities differ.

In the preference test, the only differences reported between white light and particular colors were for blue and red. The greater preference for white over blue light may be due to the fact that, in the maternity environment, the animals were already accustomed to color spectrum bands close to white, because the nurseries were heated with white incandescent lamps. TANIDA et al. (1996) pointed outthat pigs and piglets tend to illuminate their home environment.FRASER and MATTHEWS (1997) warned not to confuse animal preference with their familiar environment, so as to avoid spurious results.

As with humans, perception of bluer light resembles noon illumination, and wavelengths in yellow and red are similar sunset (TAYLOR, 2010). Both domestic and non-domestic pigs usually have low activity during the night, so providing a low light environment would be adequate for rest or sleep (TAYLOR et al., 2006). In the present research, this may explain the rejection of blue light by piglets: they were motivated to find a place to rest with low (not high) light intensity (in the maternity with blue light).

There was a significant difference on the preference test when comparing the various colors (green, blue, yellow and red). Among the various colors, the piglets preferred green, indicated by the significantly longer permanence of the piglets in these boxes longer. TAYLOR (2010) pointed out that there are no fundamentals suggesting that different spectra affect pigs in different age groups or production stages. Nevertheless, this author stated that the provision of a place where animals have the sensation of being protected, such as the construction of shelters with foliage, which have illumination corresponding to the intermediate range of the spectrum (the equivalent of green), could explain the preference for green in the present study.

When we projected the results obtained in the preference test, at the validation stage, the average percentage of piglet permanence inside the shelter shelters did not differ significantly. In other words, none of the light colors influenced the piglets' behavior in accessing and remaining in the shelter, during both the evaluation periods and the defined time periods (Table 1 and Figure 7).

The result of the validation test can be explained by the influence of inadequate ambient temperatures (average $26^{\circ} \mathrm{C}$ ) during the evaluation days; i.e., it was not cold enough for the piglets to enter the nursing shelters. Another explanation is that, regardless of temperature, piglets are highly motivated to remain in a group, even in a lower temperature area, than to be alone in a heated area (HRUPKAET al., 2000). Furthermore, piglets tend to lie close to their mother for the first three days of life(HRUPKAET al., 1998).

Separation into distinct analysis periods (the whole period versus the first ten days of life) and distinct time ranges (all times versus from 0200h to

Table 1 - Means and standard errors of the percentage of retention piglets remaining as a function of the period (days of assessment and times of behavioral registration) and treatment during the swine maternity validation test.

\begin{tabular}{|c|c|c|c|}
\hline \multirow[t]{2}{*}{ Period ${ }^{*}$} & \multicolumn{2}{|c|}{ 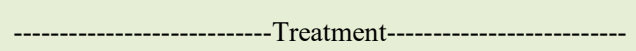 } & \multirow[t]{2}{*}{$\operatorname{Pr}>\mathrm{F}$} \\
\hline & White light & Green light & \\
\hline All days and times evaluated & $13.84 \pm 2.07$ & $13.59 \pm 2.79$ & 0.9152 \\
\hline Every day from 2 am to 9 am & $23.30 \pm 3.36$ & $20.44 \pm 4.50$ & 0.5060 \\
\hline From $1^{\text {st }}$ to the $10^{\text {th }}$ day at all times & $11.91 \pm 1.91$ & $11.57 \pm 2.63$ & 0.8961 \\
\hline From the $1^{\text {st }}$ to the $10^{\text {th }}$ dayfrom 2 am to 9 am & $21.76 \pm 3.87$ & $17.59 \pm 4.37$ & 0.4295 \\
\hline
\end{tabular}

*Statistical analysis with time filters (all day versus 2 am to 9 am) and evaluation periods (all the periods versus only the first ten days of age), so as to demonstrate periods of longer stays inside the nursing shelter. 


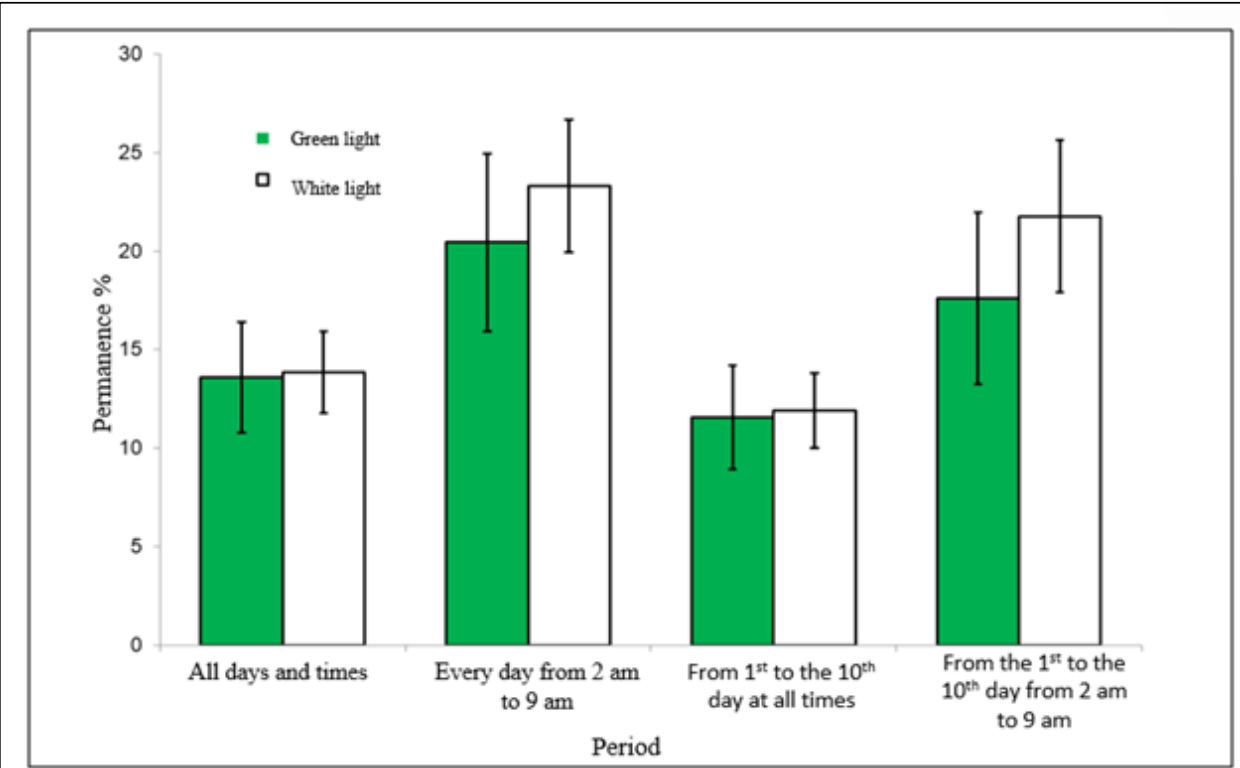

Figure 7 - Mean percentage and standard error of piglet stays in the nursery as a function of assessment days, behavioral registration and treatment times during the validation test.

0900h) showed no effect of treatments on piglet behavior (Table 1 and Figure 7), despite the fact that this filtering of results separated the periods into more favorable temperature ranges for the piglets to actually seek out the nursing shelters (Figure 8).
Conversely, the fact that we did not confirm the preference test with the validation experiment (the permanence-times for piglets in the greenlighted shelter was the same as that of the white-lighted shelter) does not prove that there is no preference

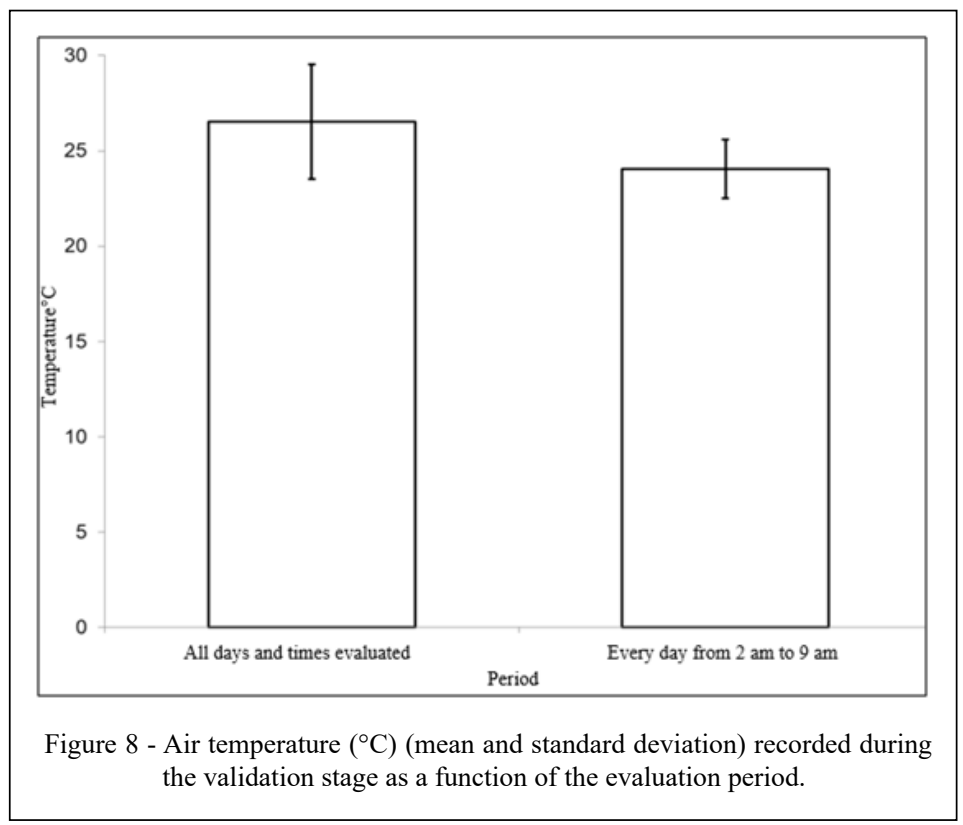

Ciência Rural, v.50, n.11, 2020. 
for green light in the nursing environment. In addition to the thermal conditions that may have influenced the permanence of piglets outside the nursing shelter, in the validation experiment, the animals had no other option than the one offered for the respective treatments. According to FRASER and MATTHEWS (1997), what is preferred by animals at a given period tends to vary according to age, experience, time of day, environmental conditions and behavior, such that preference experiments need to be sufficiently long to detect foci of variation. Accessing an environment where any of the available resources is not preferred may be a factor that negatively affects animal welfare.

\section{CONCLUSION}

Piglets demonstrated the ability to prefer alternative light colors in the nursing shelter. Compared to white, blue and red lights were not attractive; however, among alternative colors (green, blue, yellow and red) piglets preferred green lighting at between two and five days of age.In the nursing environment, the light color used in the creep area did not influence piglet behavior, thereby excluding the effect of light on piglet preferences.

\section{ACKNOWLEDGEMENTS}

The experimentewasfinanced in partbythe Coordenação de Aperfeiçoamento de Pessoal de Nível Superior (CAPES), Brasil - Financecode 001.”

\section{DECLARATION OF CONFLICTS OF INTERESTS}

The authors declare no conflicts of interest. The funding sponsors had no role in the design of the study; in the collection, analyses, or interpretation of the data; in the writing of the manuscript; or in the decision to publish the results.

\section{AUTHORS' CONTRIBUTIONS}

The authors contributed equally to the manuscript.

\section{REFERENCES}

DELIGEORGIS, S.G.;etal.,.The influence of drinker location and colour on drinking behavior and water intake in newborn pigs under hot environments. Applied Animal Behaviour Science, v.96, n.3-4, p.233-244, 2005. Available from: <https:/www.sciencedirect.com/science/article/abs/pii/S0168159105001516>.Accessed: Jan. 08, 2019. doi: 10.1016/j.applanim.2005.06.006.

FERREIRA, R.A.;et al., Comportamento e parâmetros fisiológicos de leitões nas primeiras 24 horas de vida. Ciência e Agrotecnologia, v.31, n.6, p.1845-1849, 2007. Available from: <https://www. scielo.br/scielo.php?script=sci_abstract\&pid=S14137054200700 0600036\&lng $=$ en\&nrm=iso\&tlng=pt $>$. Acecessed: Jan. 05, 2019. doi: $10.1590 / \mathrm{S} 1413-70542007000600036$.
FRASER, D., e MATTHEWS, L.R. Preference and motivation testing.In M.C. Appleby \& B.O. Hughes (Eds.) Animal Welfare. New York: CAB International, p.159-173, 1997. Available from: $<$ https://animalstudiesrepository.org/cgi/viewcontent.cgi?article $=1$ 001\&context=valaexp $>$. Accessed: Jan. 05, 2019.

HRUPKA, B.J., et al., The effect of thermal environment and age on neonatal behavior. Journal Animal Science, v.78, n.3, p. 583-591, 2000. Available from: <https://pubmed.ncbi.nlm. nih.gov/10764064/>. Accessed: Jan. 05, 2019. doi: https://doi. org/10.2527/2000.783583x.

HRUPKA, B.J., et al, The effect of farrowing crate heat lamp location on sow and pig patterns of lying and pig survival. Journal Animal Science, v.76, p.2995-3002, 1998. Available from: $<$ https://pubmed.ncbi.nlm.nih.gov/9928603/>. Accessed: Jan. 05, 2019. doi: $10.2527 / 1998.76122995 x$.

KITTAWORNRAT, A.; ZIMMERMAN, J.J. Toward a better understanding of pig behavior and pig welfare. Animal Health Research Reviews, v.12, n.1, p.25-32, 2010. Available from: $<$ https:// pubmed.ncbi.nlm.nih.gov/21092389/>. Accessed: Jan. 05,2019. doi: $10.1017 / \mathrm{S} 1466252310000174$.

KLOCEK, C.; et al.Colour preferences in pigs. Scientific Annals of Polish Society of Animal Production, v.12, n.4, p.123129, 2016. Available from: <http://rn.ptz.icm.edu.pl/wp-content/ uploads/2017/01/11-Klocek-ang.-pdf.pdf $>$. Accessed: Jan. 05, 2019.

LARSEN, M.L.V.;et al.,. Radiant heat increases piglets' use of the heated creep area on the critical days after birth. Livestock Science, n.1, v.201, p.74-77, 2017. Available from: $<$ https://www.sciencedirect.com/science/article/abs/pii/ S187114131730149X?via\%3Dihub>. Accessed: Jan. 06, 2019. doi: 10.1016/j.livsci.2017.05.008.

LARSEN; M. L. V.; PEDERSEN, L. J. Does light attract piglets to the creep area? Animal, v.9, n.6, p. 1032-1037, 2015.Available form: <https://pubmed.ncbi.nlm.nih.gov/25711807/>. Accessed: Jan. 06, 2019. doi: 10.1017/S1751731115000257.

ROHDE, P. K.A e GONYOU, H.W. Attraction of newborn piglets to auditory, visual, olfactory and tactile stimuli. Journal of Animal Science, v.69, p.125-133, 1991. Available from: <https://academic.oup.com/jas/article-abstract/69/1/125/4631853?redirectedFrom $=$ fulltext $>$. Accessed: Jan. 08, 2019. doi: 10.2527/1991.691125x.

SAS INSTITUTE INC. System for Microsoft Windows, Release 9.4, Cary, NC, USA, 2002-2012. (cd-rom).

TANIDA, H.; et al., Behavioural responses of piglets to darkness and shadows. Applied Animal Behaviour Science, v.49, p.173183, 1996. Available from: <https://www.sciencedirect.com/science/article/abs/pii/0168159196010398?via\%3Dihub>. Accessed: Jan. 08, 2019. doi: 10.1016/0168-1591(96)01039-8.

TANIDA, H.;et al., . Color Discrimination in Weanling Pigs. Animal Science Technology, v.62, n.11, p.1029-1034, 1991. Available from: <https://www.jstage.jst.go.jp/article/chikusan1924/62/11/62 11 1029/article>. Accessed: Jan.07, 2019. doi: 10.2508 /chikusan.62.1029.

TAYLOR, N. Lighting for Pig Units. 2010. Available from: $<$ https://pork.ahdb.org.uk/media/39814/lighting-for-pig-unitsfinal-report.pdf $>$. Accessed: Dec. 16, 2018. 
TAYLOR, N.; et al., Preference of growing pigs for illuminance. Applied Animal Behaviour Science, v.96, n.1-2, p.19-31, 2006. Available from: <https:/www.sciencedirect.com/science/article/ abs/pii/S0168159105001231?via\%3Dihub>Accessed: Jan.08, 2019.doi:10.1016/j.applanim.2005.04.016.

VASDAL, G.; et al., Piglet use of the creep area-Effects of breeding value and farrowing environment. Applied Animal Behaviour Science, v.120, n.1-2, p.62-67, 2009.Available from: $<$ https://www.sciencedirect.com/science/article/abs/pii/S016815910900183X $>$ Accessed: Jan. 07, 2019. doi: 10.1016/j.applanim.2009.05.014.
VASDAL, G.; et al., Increasing the piglets' use of the creep area-A battle against biology?Applied Animal Behavior Science, v.125, p.96-102, 2010a. Available from: <https:/www.sciencedirect. com/science/article/abs/pii/S0168159110001310?via\%3Dihub>. Accessed: Jan. 08, 2019.doi: 10.1016/j.applanim.2010.04.010.

VASDAL, G.;et al., . Piglet preference for infrared temperature and flooring. Applied Animal Behaviour Science, v.122, n.2-4, p.92-97, 2010b.Available from: <https://www.sciencedirect.com/ science/article/abs/pii/S0168159109003529?via\%3Dihub>. Accessed: Jan. 08, 2019. doi: 10.1016/j.applanim.2009.12.008. 